\title{
Impact of rewarming rate on the mortality of patients with accidental hypothermia: analysis of data from the J-Point registry
}

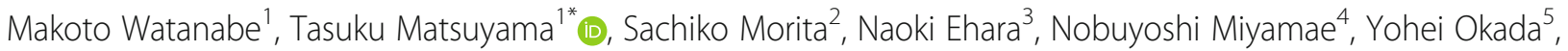
Takaaki Jo ${ }^{6}$, Yasuyuki Sumida ${ }^{7}$, Nobunaga Okada ${ }^{1,8}$, Masahiro Nozawa $^{9}$, Ayumu Tsuruoka ${ }^{10,11}$, Yoshihiro Fujimoto ${ }^{3}$, Yoshiki Okumura ${ }^{12}$, Tetsuhisa Kitamura ${ }^{13}$ and Bon Ohta ${ }^{1}$

\begin{abstract}
Background: Accidental hypothermia (AH) is defined as an involuntary decrease in core body temperature to $<35^{\circ} \mathrm{C}$. The management of $\mathrm{AH}$ has been progressing over the last few decades, and numerous techniques for rewarming have been validated. However, little is known about the association between rewarming rate (RR) and mortality in patients with $\mathrm{AH}$.
\end{abstract}

Method: This was a multicentre chart review study of patients with AH visiting the emergency department of 12 institutions in Japan from April 2011 to March 2016 (Japanese accidental hypothermia network registry, J-Point registry). We retrospectively registered patients using the International Classification of Diseases, Tenth Revision code T68: 'hypothermia'. We excluded patients whose body temperatures were unknown or $\geq 35^{\circ} \mathrm{C}$, who could not be rewarmed, whose rewarmed temperature or rewarming time was unknown, those aged $<18$ years, or who or whose family members had refused to join the registry. RR was calculated based on the body temperature on arrival at the hospital, time of arrival at the hospital, the documented temperature during rewarming, and time of the temperature documentation. RR was classified into the following five groups: $\geq 2.0^{\circ} \mathrm{C} / \mathrm{h}, 1.5-<2.0^{\circ} \mathrm{C} / \mathrm{h}, 1.0-$ $<1.5^{\circ} \mathrm{C} / \mathrm{h}, 0.5-<1.0^{\circ} \mathrm{C} / \mathrm{h}$, and $<0.5^{\circ} \mathrm{C} / \mathrm{h}$. The primary outcome of this study was in-hospital mortality. The association between RR and in-hospital mortality was evaluated using multivariate logistic regression analysis.

Result: During the study, 572 patients were registered in the J-Point registry, and 481 patients were included in the analysis. The median body temperature on arrival to the hospital was $30.7^{\circ} \mathrm{C}$ (interquartile range [IQR], $\left.28.2^{\circ} \mathrm{C}-32.4^{\circ} \mathrm{C}\right)$, and the median RR was $0.85^{\circ} \mathrm{C} / \mathrm{h}\left(\mathrm{IQR}, 0.53^{\circ} \mathrm{C} / \mathrm{h}-1.31^{\circ} \mathrm{C} / \mathrm{h}\right)$. The in-hospital mortality rates were $19.3 \%(11 / 57), 11.1 \%(4 / 36), 14.4 \%(15 / 104), 20.1 \%(35 / 175)$, and $34.9 \%(38 / 109)$ in the $\geq 2.0^{\circ} \mathrm{C} / \mathrm{h}$, $1.5-<2.0^{\circ} \mathrm{C} / \mathrm{h}, 1.0-<1.5^{\circ} \mathrm{C} / \mathrm{h}, 0.5-<1.0^{\circ} \mathrm{C} / \mathrm{h}$, and $<0.5^{\circ} \mathrm{C} / \mathrm{h}$ groups, respectively. Multivariate regression analysis revealed that in-hospital mortality rate increased with each $0.5^{\circ} \mathrm{C} / \mathrm{h}$ decrease in RR (adjusted odds ratio, 1.49; 95\% confidence interval, 1.15-1.94; $\left.P_{\text {trend }}<0.01\right)$.

Conclusion: This study showed that slower RR is independently associated with in-hospital mortality.

Keywords: Accidental hypothermia, Rewarming, Rewarming rate

\footnotetext{
* Correspondence: task-m@koto.kpu-m.ac.jp

${ }^{1}$ Department of Emergency Medicine, Kyoto Prefectural University of

Medicine, Kamigyo-ku, Kyoto 602-8566, Japan

Full list of author information is available at the end of the article
}

(C) The Author(s). 2019 Open Access This article is distributed under the terms of the Creative Commons Attribution 4.0 International License (http://creativecommons.org/licenses/by/4.0/), which permits unrestricted use, distribution, and reproduction in any medium, provided you give appropriate credit to the original author(s) and the source, provide a link to the Creative Commons license, and indicate if changes were made. The Creative Commons Public Domain Dedication waiver (http://creativecommons.org/publicdomain/zero/1.0/) applies to the data made available in this article, unless otherwise stated. 


\section{Background}

Accidental hypothermia $(\mathrm{AH})$ is defined as an involuntary decrease in core body temperature to $<35^{\circ} \mathrm{C}[1]$. $\mathrm{AH}$ cases are frequently observed in the emergency department and can present significant problems. A previous study has stated that the mortality rate of patients with $\mathrm{AH}$ was as high as approximately $30 \%$ [2]. Severe hypothermia (body core temperature $<28^{\circ} \mathrm{C}$ ) was specifically associated with a high risk of sudden cardiac arrest [3]. The management of $\mathrm{AH}$ has been progressing over the last few decades, and numerous techniques for rewarming have been validated [4-6]; however, little is known about the optimal rewarming rate (RR).

Theoretically, it seems reasonable to rewarm patients with $\mathrm{AH}$ as fast as possible to avoid the fatal complications of hypothermia such as cardiac instability $[1,5]$. Conversely, rewarming is associated with a number of complications: for example, hypotension, neutropenia, thrombocytopenia, electrolyte changes, cardiac arrhythmias, gastrointestinal bleeding, and infection [4, 6-9]. These complications may consequently affect the mortality rate as a number of deaths in patients with $\mathrm{AH}$ have been noted after successful rewarming [6]. Hence, the selection of appropriate rewarming strategies, including $\mathrm{RR}$, is considered the major problem in AH. Suggestions about RR vary among studies; some studies suggest the benefit of rapid $R R[4,5,10]$, while other studies do not $[6,11-13]$. These suggestions are based on small observational studies, animal studies, and studies in cardiac surgery. Thus, existing guidelines do not mention the optimal RR because of insufficient evidence [1, 3].

We performed the Japanese accidental hypothermia network registry (J-Point registry), a multicentre retrospective observational study, which enrolled 481 adult patients with $\mathrm{AH}$. Using this registry, we evaluated the association between RR and in-hospital mortality.

\section{Methods}

\section{Study design and setting}

We conducted a multicentre chart review study of patients with $\mathrm{AH}$ visiting the emergency departments of 12 institutions in Japan (Japanese accidental hypothermia network registry [J-Point registry]). The Japanese AH network comprises eight critical care medical centres (CCMCs) and four non-CCMCs with an emergency department across the Kyoto, Osaka, and Shiga Prefectures in Japan. For the participating institutions, the median annual emergency department visit volume was 19,651 (interquartile range [IQR], 13,281-27,554). Using these data, we evaluated the association between RR and mortality.

\section{Participants}

We retrospectively registered patients using the International Classification of Diseases, Tenth Revision (ICD-
10) code T68: 'hypothermia' from April 2011 to March 2016. We excluded patients whose body temperatures were unknown or $\geq 35^{\circ} \mathrm{C}$, who could not be rewarmed, whose rewarmed temperature or rewarming time was unknown, aged $<18$ years, or those who or whose family members had refused to join the registry.

\section{Data collection and quality control}

The details of the methodology were described previously [14]. In summary, all chart reviewers were emergency physicians who underwent training for appropriate data extraction. A predefined uniform datasheet was used for data collection.

Collected baseline patient characteristics were as follows: sex, age, activities of daily living (ADLs) before the emergency department visit (independent, needing some assistance, or needing total assistance), residence (living at home alone, living at home but not alone, nursing home, or homeless), medical history (cardiovascular disease, neurological disease, endocrine disease, psychiatric disease, malignant disease, or dementia, or others), location (indoor or outdoor), and mode of arrival (walk-in or transported using an ambulance).

The data collected upon arrival at the hospital were as follows: vital signs upon arrival at the hospital (body temperature, blood pressure, heart rate, and Glasgow Coma Scale [GCS] score), biological data (serum $\mathrm{pH}$, bicarbonate $\left[\mathrm{HCO}_{3}-\right][\mathrm{mEq} / \mathrm{L}]$, lactate $[\mathrm{mmol} / \mathrm{L}]$, sodium $[\mathrm{mEq} / \mathrm{L}]$, potassium $[\mathrm{mEq} / \mathrm{L}]$, and glucose $[\mathrm{mg} / \mathrm{dL}]$ levels), cold exposure, associated conditions, treatment process, and outcome. The presence of cold exposure, which is a possible cause of the hypothermia, was determined by the clinician who cared for the patient or who entered the data of this study. The Sequential Organ Failure Assessment (SOFA) score was only calculated for patients admitted to the intensive care unit. Consistent with a previous study [2], associated conditions were classified into internal disease, traumatic injury, alcohol intoxication, drowning, and self-harm, and others. The diagnoses of internal disease were obtained from ICD-9 or ICD-10 code in the medical records. Rewarming procedures were divided into active exter$\mathrm{nal} / \mathrm{minimally}$ invasive rewarming (warm intravenous fluids, warm blanket, forced warm air, heating pads, and warm bath) and active internal rewarming (lavage, intravascular haemodialysis, and extracorporeal membrane oxygenation) [15]. Other treatment information included endotracheal intubation, use of catecholamines, and emergent transvenous cardiac pacing. The data collected on the outcomes were in-hospital mortality and the incidence of ventricular fibrillation or pulseless ventricular tachycardia (VF/VT). 


\section{Outcome measures}

In this study, the primary outcome was in-hospital mortality, and the secondary outcome was the incidence of VF/VT. We calculated RR based on the body temperature upon arrival, documented temperature during rewarming, and time spent for the rewarming. We evaluated the association between $R R$ and these outcomes.

\section{Statistical analysis}

Patients were divided into the following five groups according to their RR: $\geq 2.0^{\circ} \mathrm{C} / \mathrm{h}, 1.5-<2.0^{\circ} \mathrm{C} / \mathrm{h}, 1.0-<$ $1.5^{\circ} \mathrm{C} / \mathrm{h}, 0.5-<1.0^{\circ} \mathrm{C} / \mathrm{h}$, and $<0.5^{\circ} \mathrm{C} / \mathrm{h}$. Patients' characteristics, in-hospital information, and outcomes were evaluated between the five groups using Kruskal-Wallis tests for continuous variables and Fisher's exact tests for categorical variables. For the post-hoc analyses of these tests, Steel-Dwass multiple comparison tests and Bonferroni correction for multiple comparisons were used, respectively. Regarding the primary outcome, the association between each category of the RR and inhospital mortality was evaluated using the univariate and multivariate logistic regression analyses, with crude or adjusted odds ratios (AORs) and their 95\% confidence interval (CI) as the effect variables. In multivariate models, we selected the potential confounders that were considered to be associated with the clinical outcomes, including sex, age category (adults aged 18-64 years, the young-elderly aged 65-74 years, or the elderly-elderly aged $\geq 75$ years), body temperature at arrival to the hospital (mild $\left[\geq 32^{\circ} \mathrm{C}\right]$, moderate $\left[28-32^{\circ} \mathrm{C}\right]$, and severe $\left[<28^{\circ} \mathrm{C}\right]$ ), the number of past medical history (none, one, or multiple), ADLs (independent, need for some assistance, need for total assistance, or unknown), systolic blood pressure (cardiac arrest, unmeasurable, 40-90 $\mathrm{mmHg}$, or $90<\mathrm{mmHg}$ ), cold exposure (yes, no, or unknown), presence of associated internal diseases (yes or no), and active internal rewarming (yes or no). Regarding the secondary outcome, the association between each category of the RR and occurrence of VF/VT was evaluated using the univariate logistic regression analyses, with crude odds ratios and their $95 \% \mathrm{CI}$ as the effect variables. Additionally, we divided the patients into subgroups according to age category (adults aged 18-64 years, elderly patients aged $\geq 65$ years), location (indoor, outdoor), body temperature at arrival to the hospital (mild, moderate, severe), associated conditions (presence of associated internal disease or not), and rewarming procedure (use of active internal rewarming or not). The association between each category of the RR and inhospital mortality was evaluated in the same way as the primary outcome. All $P$ values were two-sided, and 0.05 levels were considered statistically significant. All statistical analyses were performed using the Statistical
Package for the Social Sciences software (V.24 J), R (The R Foundation for Statistical Computing, version 3.30, Saitama, Japan), and EZR (Saitama Medical Center, Jichi Medical University, version 1.32, Saitama, Japan), which is a graphical user interface for $\mathrm{R}$ [16].

\section{Result}

During the study period, 572 patients were registered in the J-Point registry; out of which, 27 patients whose body temperature was $\geq 35^{\circ} \mathrm{C}, 8$ patients aged $<18$ years, 2 patients who could not be rewarmed, and 54 patients whose rewarmed temperature or rewarming time were unknown were excluded in the study (Fig. 1). We finally enrolled 481 patients for the analysis.

\section{Patient characteristic and in-hospital data}

The baseline patients' characteristics are presented in Table 1. Approximately half of the patients were male (50.5\%), and the median age was 79 years (IQR, 67-87 years). Overall, $78 \%$ of the patients had $\mathrm{AH}$ in an indoor setting. Patients were younger in the $\geq 2.0^{\circ} \mathrm{C} / \mathrm{h}$ group. Patients in the $<0.5^{\circ} \mathrm{C} / \mathrm{h}$ groups were more likely to have decreased ADLs and lived in nursing homes. There was no significant difference in the number and types of past medical history among the five groups.

The in-hospital data are presented in Table 2 . The median body temperature was $30.7^{\circ} \mathrm{C}$ (IQR, $28.2-32.4^{\circ} \mathrm{C}$ ), and the median RR was $0.85^{\circ} \mathrm{C} / \mathrm{h}$ (IQR, $0.53-1.31^{\circ} \mathrm{C} / \mathrm{h}$ ). Most of the patients received active external or minimally invasive rewarming, whereas about one in six patients received active internal rewarming. The percentage of patients with cardiac arrest was highest in the $>2.0^{\circ} \mathrm{C} / \mathrm{h}$ group. Acid-base status abnormality $(\mathrm{pH}$, lactate, and $\mathrm{HCO}_{3}-$ ) are more common in the $>2.0^{\circ} \mathrm{C} / \mathrm{h}$ group, but serum sodium and potassium levels did not differ among the five groups. There was no significant difference in GCS and SOFA score. The prevalence of internal disease association was significantly high in the $<0.5^{\circ} \mathrm{C} / \mathrm{h}$ group.

\section{Outcome}

The outcomes of this study are presented in Table 3 . The in-hospital mortality rates were $19.3 \%$ (11/57), $11.1 \%(4 / 36), 14.4 \%$ (15/104), $20.1 \%(35 / 175)$, and $34.9 \%$ $(38 / 109)$ in the $\geq 2.0^{\circ} \mathrm{C} / \mathrm{h}, 1.5-<2.0^{\circ} \mathrm{C} / \mathrm{h}, 1.0-<1.5^{\circ} \mathrm{C} / \mathrm{h}$, $0.5-<1.0{ }^{\circ} \mathrm{C} / \mathrm{h}$, and $<0.5^{\circ} \mathrm{C} / \mathrm{h}$ groups, respectively. Multivariate regression analysis revealed that the in-hospital mortality rate increased with each $0.5{ }^{\circ} \mathrm{C} / \mathrm{h}$ decrease in RR (AOR, 1.49; 95\% CI, 1.15-1.94; $P_{\text {trend }}<0.01$ ). Additionally, the mortality rate was significantly higher in the $<0.5^{\circ} \mathrm{C} / \mathrm{h}$ group than in the $\geq 2.0^{\circ} \mathrm{C} / \mathrm{h}$ group (AOR, 4.09; 95\% CI, 1.33-12.6). Regarding the case of the secondary outcome, univariate logistic analysis revealed that the incidence of VF/VT decreased with each $0.5^{\circ} \mathrm{C} / \mathrm{h}$ 
Patients with the International Classification of Diseases, Tenth Revision (ICD-10) code T68: "hypothermia" from April 2011 to March 2016.

$\mathbf{N}=\mathbf{5 7 2}$

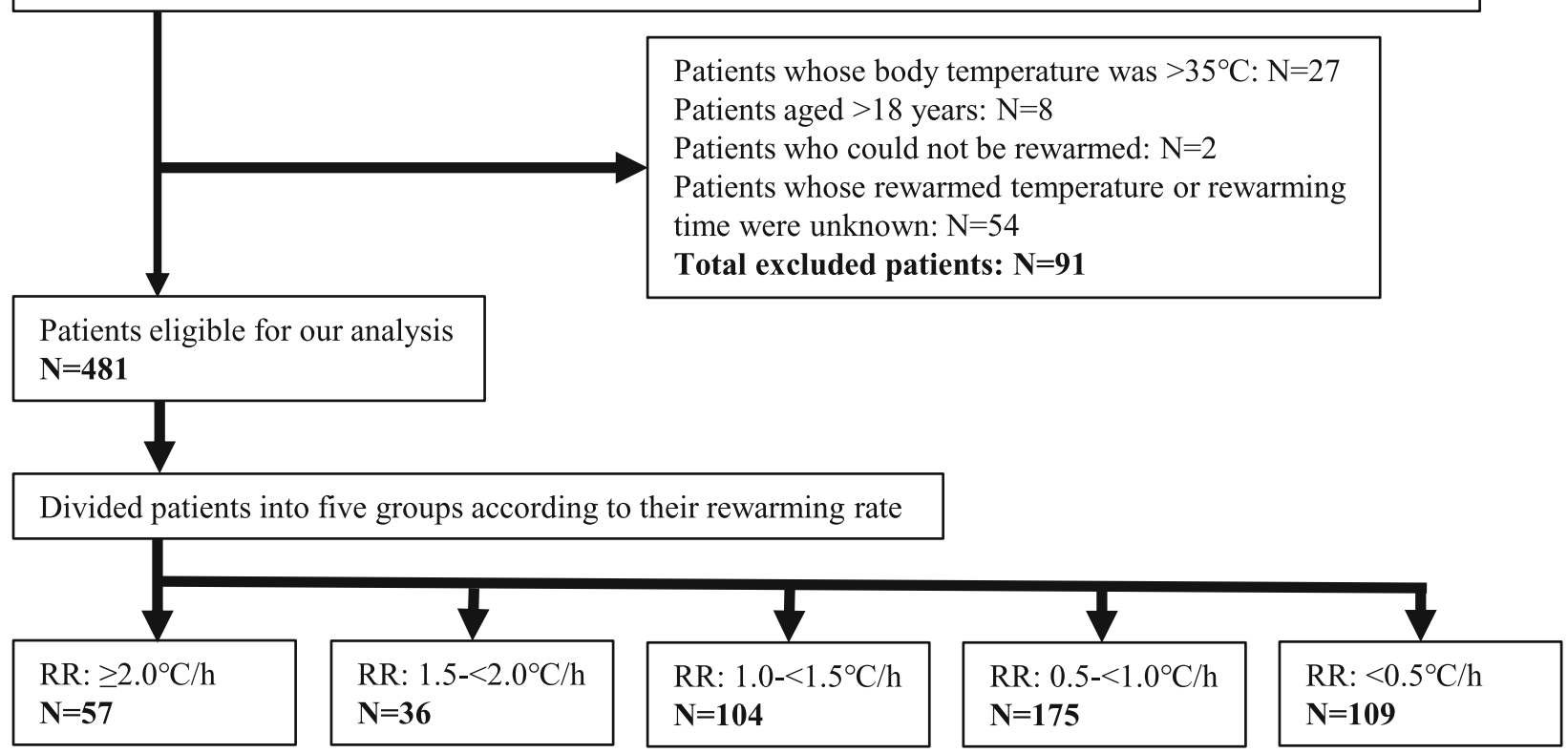

Fig. 1 Study flowchart

decrease in RR (AOR, 0.55; 95\% CI, 0.33-0.90; $P_{\text {trend }}=$ 0.016). According to the subgroup analysis, although each analysis showed heterogeneity and under power, the negative association of $R R$ and mortality was constant (Table 4).

\section{Discussion}

In this study, we found that the RR of patients with $\mathrm{AH}$ is independently associated with mortality after adjusting the important potentially confounding factors. Inhospital mortality rates increase with each $0.5^{\circ} \mathrm{C} / \mathrm{h}$ decrease in RR. Furthermore, the mortality rate in the < $0.5^{\circ} \mathrm{C} / \mathrm{h}$ group was significantly higher than that in the $>2.0^{\circ} \mathrm{C} / \mathrm{h}$ group. To the best of our knowledge, this is the first multicentre study to assess the association between RR and mortality, and the findings of this study may provide important information regarding the appropriate treatment of $\mathrm{AH}$.

We initially show that patients with slower RR have the following characteristics: are more likely to be older, have lower body temperature at arrival to the hospital, and have an internal disease. This result is consistent with that of the previous studies $[6,17]$. However, the $\mathrm{RR}$ in this study was slower than that in the previous studies because of the older age of our study population [10]. Another possible reason is the high proportion of the patients who developed $\mathrm{AH}$ in an indoor setting, which might be the result of underlying diseases such as infections [18].

Previous studies have suggested a possible association between RR and mortality. Daniel et al. reported that the mean RR in patients with AH who died was significantly slower than that in surviving patients in a retrospective multicentre observational study [17]. Kathleen et al. reported that the likelihood of mortality was associated with slower RR in a single-centre observational study, which included 96 patients [18]. These results are, although not the main outcome of the studies and derived from univariate analysis, consistent with the results of our study. In this study, we confirmed the negative association between RR and mortality using multivariate logistic analysis with 481 patients, which is the largest sample size in this field.

There are several known physiological effects of hypothermia that could result in high mortality. Cardiac contractility and pulse rate decrease as the heart cools $[1,3,8]$. Cold stress reduces the circulating blood volume due to cold-induced diuresis, extravascular plasma shift, and inadequate fluid intake $[6,19,20]$. Both hypoand hyper-kalaemia occur in patients with $\mathrm{AH}$ due to the shift of extracellular potassium into the cells, acidosis, and cell death [8, 21]. Ventilatory response to carbon dioxide is attenuated and results in respiratory acidosis $[3,22]$. These cardiorespiratory effects may lead to the clinical manifestations of shock and dysrhythmia 
Table 1 Baseline characteristics of the study population according to their rewarming rate category

\begin{tabular}{|c|c|c|c|c|c|c|c|}
\hline & \multirow{3}{*}{$\begin{array}{l}\text { All } \\
\text { patients } \\
n=481\end{array}$} & \multicolumn{5}{|c|}{ Rewarming rate $\left({ }^{\circ} \mathrm{C} / \mathrm{h}\right)$} & \multirow[t]{3}{*}{$P$ values* } \\
\hline & & $(\geq 2.0)$ & $(1.5-<2.0)$ & $(1.0-<1.5)$ & $(0.5-<1.0)$ & $(<0.5)$ & \\
\hline & & $n=57$ & $n=36$ & $n=104$ & $n=175$ & $n=109$ & \\
\hline Men & $243(50.5)$ & $25(43.9)$ & $14(38.9)$ & $56(53.8)$ & $93(53.1)$ & $55(50.5)$ & 0.424 \\
\hline Age, y, median (IQR) & $79(67-87)$ & $71(64-81)^{a, b}$ & $77(68-85)$ & $76(64-87)$ & $82(70-87)^{a}$ & $81(72-89)^{b}$ & 0.002 \\
\hline \multicolumn{8}{|l|}{ Age category } \\
\hline Adults aged $18-64$ years & $101(21.0)$ & $15(26.3)$ & $8(22.2)$ & $27(26.0)$ & $35(20.0)$ & $16(14.7)$ & 0.240 \\
\hline Young-elderly aged $65-74$ years & 79 (16.4) & $18(31.6)^{a}$ & $7(19.4)$ & $18(17.3)$ & $20(11.4)^{a}$ & $16(14.7)$ & 0.014 \\
\hline Elderly-elderly aged $\geq 75$ years & $301(62.6)$ & $24(42.1)^{a, b}$ & $21(58.3)$ & $59(56.7)$ & $120(68.6)^{a}$ & $77(70.6)^{b}$ & 0.002 \\
\hline \multicolumn{8}{|l|}{ Activity of daily living } \\
\hline Independent & $335(70.0)$ & $49(86.0)^{a}$ & $30(83.3)^{b}$ & $74(71.2)$ & $121(68.4)$ & $61(56.0)^{a, b}$ & $<0.001$ \\
\hline Need for some assistance & $114(23.7)$ & $8(14.0)$ & $5(13.9)$ & $28(26.9)$ & $44(25.3)$ & $29(26.6)$ & 0.183 \\
\hline Need for total assistance & $31(6.4)$ & $0(0.0)^{\mathrm{a}}$ & $1(2.8)$ & $2(1.9)^{b}$ & $10(6.3)^{c}$ & $18(16.5)^{a, b, c}$ & $<0.001$ \\
\hline Unknown & $1(0.21)$ & $0(0.0)$ & $0(0.0)$ & $0(0.0)$ & $0(0.0)$ & $1(0.9)$ & \\
\hline \multicolumn{8}{|l|}{ Residence } \\
\hline Home & $432(89.8)$ & $53(93.0)$ & $34(94.4)$ & $101(97.1)^{a}$ & $156(89.1)$ & $88(80.7)^{a}$ & 0.002 \\
\hline Living alone & $193(40.1)$ & $17(29.8)$ & $19(52.8)$ & $51(49.0)^{a}$ & $75(42.9)$ & $31(28.4)^{a}$ & 0.004 \\
\hline Living not alone & $239(49.7)$ & $36(63.2)$ & $15(41.7)$ & $50(48.1)$ & $81(46.3)$ & $57(52.3)$ & 0.180 \\
\hline Nursing home & $30(6.2)$ & $0(0.0)^{\mathrm{a}}$ & $1(2.8)$ & $1(1.0)^{\mathrm{b}}$ & $11(6.3)$ & $17(15.6)^{a, b}$ & $<0.001$ \\
\hline Homelessness & $4(0.8)$ & $0(0.0)$ & $1(2.8)$ & $0(0.0)$ & $2(1.1)$ & $1(0.9)$ & 0.496 \\
\hline Unknown & $15(3.1)$ & $4(7.0)$ & $0(0.0)$ & $2(1.9)$ & $6(3.4)$ & $3(2.8)$ & \\
\hline \multicolumn{8}{|l|}{ Location } \\
\hline Indoor & $375(78.0)$ & $36(63.2)^{a, b}$ & $27(75.0)$ & $68(65.4)^{c, d}$ & $150(85.7)^{a, c}$ & $94(86.2)^{b, d}$ & $<0.001$ \\
\hline Outdoor & $106(22.0)$ & $21(36.8)^{a, b}$ & $9(25.0)$ & $36(34.6)^{c, d}$ & $25(14.3)^{a, c}$ & $15(13.8)^{b, d}$ & $<0.001$ \\
\hline \multicolumn{8}{|l|}{ Mode of arrival } \\
\hline Ambulance & $453(94.2)$ & $55(96.5)$ & $35(97.2)$ & $101(97.1)$ & $166(94.9)$ & $96(88.1)$ & 0.065 \\
\hline Walk-in & $28(5.8)$ & $2(3.5)$ & $1(2.8)$ & $3(2.9)$ & $9(5.1)$ & $13(11.9)$ & 0.065 \\
\hline \multicolumn{8}{|l|}{ Past medical history } \\
\hline Cardiovascular disease & $213(44.3)$ & $27(47.4)$ & $13(36.1)$ & 37 (35.6) & $77(44.0)$ & $59(54.1)$ & 0.070 \\
\hline Neurological disease & $86(17.9)$ & $7(12.3)$ & $4(11.1)$ & $21(20.2)$ & $31(17.7)$ & $23(21.1)$ & 0.507 \\
\hline Endocrine disease & $116(24.2)$ & $16(28.1)$ & $8(22.2)$ & $18(17.3)$ & $44(25.1)$ & $30(27.5)$ & 0.391 \\
\hline Psychiatric disease & $110(22.9)$ & 18 (31.6) & $11(30.6)$ & $24(23.1)$ & $37(21.1)$ & $20(18.3)$ & 0.261 \\
\hline Malignant disease & $50(10.4)$ & $7(12.3)$ & $3(8.3)$ & $9(8.7)$ & $23(13.1)$ & $8(7.3)$ & 0.546 \\
\hline Dementia & $99(20.6)$ & $5(8.8)$ & $7(19.4)$ & $20(19.2)$ & $39(22.3)$ & $28(25.7)$ & 0.111 \\
\hline Other & $88(18.7)$ & $7(12.3)$ & $6(16.7)$ & $19(18.3)$ & $35(20.0)$ & $21(19.3)$ & 0.784 \\
\hline Unknown & $7(1.46)$ & $1(1.8)$ & $0(0.0)$ & $1(1.0)$ & $3(1.7)$ & $2(1.8)$ & 1.000 \\
\hline \multicolumn{8}{|l|}{ Number of past medical history } \\
\hline None & $118(24.5)$ & $13(22.8)$ & $11(30.6)$ & $28(26.9)$ & $47(26.9)$ & $19(17.4)$ & 0.308 \\
\hline One & $152(31.6)$ & $18(31.6)$ & $11(30.6)$ & $37(35.6)$ & $50(28.6)$ & $36(33.0)$ & 0.803 \\
\hline Multiple & $211(43.9)$ & $26(45.6)$ & $14(38.9)$ & $39(37.5)$ & $78(44.6)$ & $54(49.5)$ & 0.464 \\
\hline
\end{tabular}

Values are expressed numbers (percentages) unless indicated otherwise

Groups that share a superscript letter were significantly different from post-hoc pairwise comparisons

* Represents P for heterogeneity across the 5 rewarming rate groups. Comparisons between the 5 groups were evaluated with Kruskal-Wallis test for numeric variables and Fisher's exact test for categorical variables. For post-hoc pairwise comparisons of these tests, Steel-Dwass multiple comparison tests and Bonferroni correction for multiple comparisons were used, respectively 
Table 2 In-hospital data of the study population according to their rewarming rate category

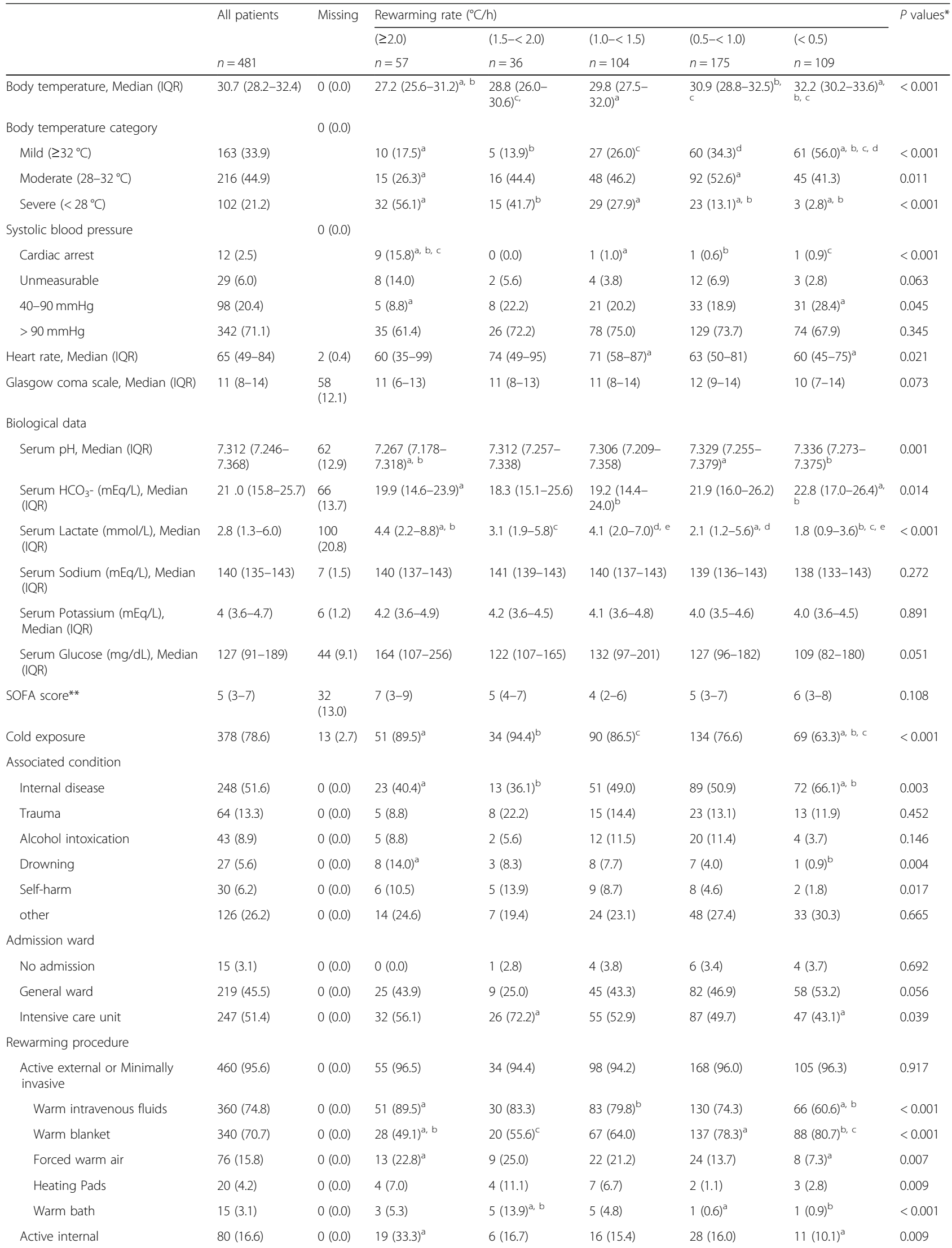


Table 2 In-hospital data of the study population according to their rewarming rate category (Continued)

\begin{tabular}{|c|c|c|c|c|c|c|c|c|}
\hline & All patients & Missing & Rewarming rat & & & & & $P$ values ${ }^{*}$ \\
\hline & & & $(\geq 2.0)$ & $(1.5-<2.0)$ & $(1.0-<1.5)$ & $(0.5-<1.0)$ & $(<0.5)$ & \\
\hline & $n=481$ & & $n=57$ & $n=36$ & $n=104$ & $n=175$ & $n=109$ & \\
\hline Lavage & $38(7.9)$ & $0(0.0)$ & $5(8.8)$ & $3(8.3)$ & $11(10.6)$ & $13(7.4)$ & $6(5.5)$ & 0.708 \\
\hline Intravascular & $4(0.8)$ & $0(0.0)$ & $0(0.0)$ & $1(2.8)$ & $0(0.0)$ & $2(1.1)$ & $1(0.9)$ & 0.496 \\
\hline Hemodialysis & $25(5.2)$ & $0(0.0)$ & $2(3.5)$ & $1(2.8)$ & $5(4.8)$ & $13(7.4)$ & $4(3.7)$ & 0.675 \\
\hline ECMO & $18(3.7)$ & $0(0.0)$ & $13(22.8)^{a, b, c}$ & $2(5.6)$ & $1(1.0)^{\mathrm{a}}$ & $1(0.6)^{b}$ & $1(0.9)^{c}$ & $<0.001$ \\
\hline Other treatment & & & & & & & & \\
\hline Intubation & $29(6.03)$ & $0(0.0)$ & $6(10.5)$ & $2(5.6)$ & $6(5.8)$ & $10(5.7)$ & $5(4.6)$ & 0.663 \\
\hline Catecholamine & $82(17.1)$ & $0(0.0)$ & $16(28.1)$ & $12(33.3)^{a}$ & $12(11.5)^{\mathrm{a}}$ & $23(13.1)$ & $19(17.4)$ & 0.005 \\
\hline $\begin{array}{l}\text { Emergent transvenous cardiac } \\
\text { pacing }\end{array}$ & $6(1.3)$ & $0(0.0)$ & $1(1.8)$ & $2(5.6)$ & $0(0.0)$ & $1(0.6)$ & $2(1.8)$ & 0.075 \\
\hline $\begin{array}{l}\text { Rewarming rate }\left({ }^{\circ} \mathrm{C} / \mathrm{h}\right) \text {, Median } \\
(\mathrm{IQR})^{\dagger}\end{array}$ & $0.85(0.53-1.31)$ & $0(0.0)$ & $2.7(2.25-3.8)$ & $1.68(1.6-1.84)$ & $1.20(1.09-1.31)$ & $0.73(0.59-0.85)$ & $0.34(0.25-0.41)$ & $<0.001$ \\
\hline
\end{tabular}

Values are expressed as numbers (percentages) unless indicated otherwise

Groups that share a superscript letter were significantly different from post-hoc pairwise comparisons

SOFA sequential organ failure assessment, ECMO extracorporeal membrane oxygenation

* Represents P for heterogeneity across the 5 rewarming rate groups. Comparisons between the 5 groups were evaluated with Kruskal-Wallis test for numeric

variables and Fisher's exact test for categorical variables. For post-hoc pairwise comparisons of these tests, Steel-Dwass multiple comparison tests and Bonferroni

correction for multiple comparisons were used, respectively

** Calculated with patients admitting to intensive care units

+ Post-hoc analysis was omitted

$[19,22]$. Cough reflex is obtunded, and ciliary activity is reduced $[1,8]$, predisposing to aspiration and pneumonia. Coagulopathy also occurs and is critical for patients with $\mathrm{AH}$ with severe trauma [23, 24]. For patients with $\mathrm{AH}$, slower RR means prolonged periods of susceptibility to these potentially harmful physiological effects and could result in a higher incidence of mortality.

Another outcome of this study is the incidence of VF/ VT. Because VF/VT in patients with AH may be unresponsive to anti-arrhythmic drug and defibrillation $[1,7$, 19, 25], they are the most critical complication during rewarming. Our data showed a positive association between RR and VF/VT. However, the incidence of VF/VT was highest in the $R R$ of the $1.5-<2.0^{\circ} \mathrm{C} / \mathrm{h}$ group and not in the fastest $R R$ group. Both rapid rewarming accompanied by rapid or unpredictable changes in myocardial temperature and slow rewarming accompanied by prolonged low core body temperature can be the predisposing factors of VT/VF [26, 27]. These factors may be counterbalanced, and thus, the occurrence of VT/VF in our study increased in the high-intermediate $R R$ group. As the number of patients who presented with VF/VT was significantly small to draw a conclusion, further study is required to confirm the association between RR and the incidence of VF/VT to establish more appropriate rewarming strategies.

The selection of the rewarming method can vary since no rewarming method has been proven to be better than the other rewarming methods. Our study has shown that regardless of the rewarming method, the RR is associated with mortality. It is reasonable to choose active internal rewarming when rewarming patients is urgent

Table 3 In-hospital mortality and the incidence of VF or pulseless VT

\begin{tabular}{|c|c|c|c|c|c|c|c|c|}
\hline & \multirow{2}{*}{$\begin{array}{l}\text { All } \\
\text { patients }\end{array}$} & \multicolumn{5}{|c|}{ Rewarming rate $\left({ }^{\circ} \mathrm{C} / \mathrm{h}\right)$} & \multirow[t]{3}{*}{ Odds for trend } & \multirow{3}{*}{$\begin{array}{l}P \text { for } \\
\text { trend }\end{array}$} \\
\hline & & $(\geq 2.0)$ & $(1.5-<2.0)$ & $(1.0-<1.5)$ & $(0.5-<1.0)$ & $(<0.5)$ & & \\
\hline & $n=481$ & $n=57$ & $n=36$ & $n=104$ & $n=175$ & $n=109$ & & \\
\hline \multicolumn{9}{|l|}{ Primary outcome } \\
\hline In-hospital mortality & $103(21.4)$ & $11(19.3)$ & $4(11.1)$ & $15(14.4)$ & $35(20)$ & $38(34.9)$ & & \\
\hline Odds ratio $(95 \% \mathrm{Cl})$ & & Reference & $0.52(0.15-1.79)$ & $0.71(0.30-1.66)$ & $1.05(0.50-2.24)$ & $2.24(1.04-4.82)$ & $1.33(1.10-1.61)$ & 0.003 \\
\hline Adjusted odds ratio $(95 \% \mathrm{Cl})^{*}$ & & Reference & $1.11(0.27-4.62)$ & $1.23(0.41-3.66)$ & $1.83(0.64-5.22)$ & $4.09(1.33-12.6)$ & $1.49(1.15-1.94)$ & 0.003 \\
\hline \multicolumn{9}{|l|}{ Secondary Outcome } \\
\hline Vf or pulseless VT during rewarming procedure & $9(1.9)$ & $2(3.5)$ & $2(5.6)$ & $4(3.8)$ & $1(0.6)$ & $0(0.0)$ & & \\
\hline Odds ratio $(95 \% \mathrm{Cl})$ & & Reference & $1.62(0.22-12.0)$ & $1.10(0.20-6.20)$ & $0.16(0.01-1.78)$ & N/A & $0.55(0.33-0.90)$ & 0.016 \\
\hline
\end{tabular}

Values are expressed as numbers (percentages) unless indicated otherwise

$V f$ ventricular fibrillation, $V T$ ventricular tachycardia, $\mathrm{Cl}$ confidence interval

* Adjusted for sex, age category, body temperature at arrival to the hospital, the number of past medical history, activity of daily living, cold exposure, systolic blood pressure, internal disease etiology, active internal rewarming procedure 
Table 4 In-hospital mortality (subgroup analysis)

\begin{tabular}{|c|c|c|c|c|c|c|c|c|}
\hline & \multirow{3}{*}{$\begin{array}{l}\text { All } \\
\text { patients } \\
n=481\end{array}$} & \multicolumn{5}{|c|}{ Rewarming rate $\left({ }^{\circ} \mathrm{C} / \mathrm{h}\right)$} & \multirow[t]{3}{*}{ Odds for trend } & \multirow{3}{*}{$\begin{array}{l}\mathrm{P} \text { for } \\
\text { trend }\end{array}$} \\
\hline & & $(\geq 2.0)$ & $(1.5-2.0)$ & $(1.0-1.5)$ & $(0.5-1.0)$ & $(<0.5)$ & & \\
\hline & & $n=57$ & $N=36$ & $n=104$ & $n=175$ & $n=109$ & & \\
\hline \multicolumn{9}{|l|}{ Age category } \\
\hline Adults aged $18-64$ years & 101 & 15 & 8 & 27 & 35 & 16 & & \\
\hline In-hospital mortality & $12(11.9)$ & $1(6.7)$ & $1(12.5)$ & $3(11.1)$ & $5(14.3)$ & $2(12.5)$ & & \\
\hline Odds ratio $(95 \% \mathrm{Cl})$ & & Reference & $2.00(0.11-37.0)$ & $1.75(0.17-18.5)$ & $2.33(0.25-21.9)$ & $2.00(0.16-24.7)$ & $1.17(0.71-1.95)$ & 0.532 \\
\hline Adjusted odds ratio $(95 \% \mathrm{Cl})^{\mathrm{a}}$ & & Reference & N/A & N/A & N/A & N/A & $1.69(0.87-3.30)$ & 0.124 \\
\hline Elderly patients aged $\geq 65$ years & 380 & 42 & 28 & 77 & 140 & 93 & & \\
\hline In-hospital mortality (\%) & $91(23.9)$ & $10(23.8)$ & $3(10.7)$ & $12(15.6)$ & $30(21.4)$ & $36(38.7)$ & & \\
\hline Odds ratio $(95 \% \mathrm{Cl})$ & & Reference & $0.38(0.10-1.55)$ & $0.59(0.23-1.51)$ & $0.87(0.39-1.98)$ & $2.02(0.89-4.61)$ & $1.33(1.08-1.64)$ & 0.008 \\
\hline Adjusted odds ratio $(95 \% \mathrm{Cl})^{\mathrm{a}}$ & & Reference & $0.68(0.15-3.17)$ & $0.83(0.27-2.55)$ & $1.49(0.51-4.37)$ & $3.68(1.15-11.8)$ & $1.53(1.15-2.04)$ & 0.004 \\
\hline \multicolumn{9}{|l|}{ Location } \\
\hline Indoor & 375 & 36 & 27 & 68 & 150 & 94 & & \\
\hline In-hospital mortality (\%) & $94(25.1)$ & $10(27.8)$ & $3(11.1)$ & $13(19.1)$ & $32(21.3)$ & $36(38.3)$ & & \\
\hline Odds ratio $(95 \% \mathrm{Cl})$ & & Reference & $0.33(0.08-1.32)$ & $0.62(0.24-1.58)$ & $0.71(0.31-1.61)$ & $1.61(0.70-3.74)$ & $1.25(1.01-1.54)$ & 0.039 \\
\hline Adjusted odds ratio $(95 \% \mathrm{Cl})^{\mathrm{b}}$ & & Reference & $0.55(0.11-2.68)$ & $0.89(0.27-2.87)$ & $1.03(0.34-3.10)$ & $2.48(0.76-8.14)$ & $1.36(1.03-1.80)$ & 0.033 \\
\hline Outdoor & 106 & 21 & 9 & 36 & 25 & 15 & & \\
\hline In-hospital mortality (\%) & $9(8.5)$ & $1(4.8)$ & $1(11.1)$ & $2(5.6)$ & $3(12.0)$ & $2(13.3)$ & & \\
\hline Odds ratio $(95 \% \mathrm{Cl})$ & & Reference & $2.50(0.14-45.0)$ & $1.18(0.10-13.8)$ & $2.73(0.26-28.4)$ & $3.08(0.25-37.5)$ & $1.32(0.75-2.32)$ & 0.330 \\
\hline Adjusted odds ratio $(95 \% \mathrm{Cl})^{\mathrm{b}}$ & & Reference & N/A & N/A & N/A & N/A & $1.98(0.58-6.76)$ & 0.273 \\
\hline \multicolumn{9}{|l|}{ Body temperature at arrival to the hospital } \\
\hline Mild $\left(\geq 32^{\circ} \mathrm{C}\right)$ & 163 & 10 & 5 & 27 & 60 & 61 & & \\
\hline In-hospital mortality (\%) & $32(19.6)$ & $0(0.0)$ & $1(20.0)$ & $3(11.1)$ & $6(10.0)$ & $22(36.1)$ & & \\
\hline Odds ratio $(95 \% \mathrm{Cl})$ & & Reference & N/A & N/A & N/A & N/A & $2.43(1.38-4.25)$ & 0.002 \\
\hline Adjusted odds ratio $(95 \% \mathrm{Cl})^{c}$ & & Reference & $N / A$ & N/A & N/A & $N / A$ & $2.21(1.15-4.25)$ & 0.017 \\
\hline Moderate $\left(28-32^{\circ} \mathrm{C}\right)$ & 216 & 15 & 16 & 48 & 92 & 45 & & \\
\hline In-hospital mortality (\%) & $45(20.8)$ & $2(13.3)$ & $1(6.2)$ & $6(12.5)$ & $21(22.8)$ & $15(33.3)$ & & \\
\hline Odds ratio $(95 \% \mathrm{Cl})$ & & Reference & $0.43(0.04-5.35)$ & $0.93(0.17-5.17)$ & $1.92(0.40-9.21)$ & $3.25(0.65-16.3)$ & $1.62(1.13-2.32)$ & 0.009 \\
\hline Adjusted odds ratio $(95 \% \mathrm{Cl})^{c}$ & & Reference & $0.79(0.05-11.9)$ & $0.82(0.12-5.62)$ & $1.69(0.28-10.2)$ & $2.86(0.43-18.9)$ & $1.48(0.96-2.28)$ & 0.078 \\
\hline Severe $\left(<28^{\circ} \mathrm{C}\right)$ & 102 & 32 & 15 & 29 & 23 & 3 & & \\
\hline In-hospital mortality (\%) & $26(25.5)$ & $9(28.1)$ & $2(13.3)$ & $6(20.7)$ & $8(34.8)$ & $1(33.3)$ & & \\
\hline Odds ratio $(95 \% \mathrm{Cl})$ & & Reference & $0.39(0.07-2.10)$ & $0.67(0.20-2.18)$ & $1.36(0.43-4.32)$ & $1.28(0.10-15.9)$ & $1.10(0.76-1.58)$ & 0.612 \\
\hline Adjusted odds ratio $(95 \% \mathrm{Cl})^{c}$ & & Reference & $0.49(0.07-3.44)$ & $0.58(0.12-2.90)$ & $1.18(0.23-6.08)$ & $2.44(0.13-47.5)$ & $1.17(0.71-1.93)$ & 0.548 \\
\hline \multicolumn{9}{|l|}{ Associated condition } \\
\hline Patients with internal disease etiology & 248 & 23 & 13 & 51 & 89 & 72 & & \\
\hline In-hospital mortality (\%) & $71(28.6)$ & $5(21.7)$ & $3(23.1)$ & $12(23.5)$ & $22(24.7)$ & $29(40.3)$ & & \\
\hline Odds ratio $(95 \% \mathrm{Cl})$ & & Reference & $1.08(0.21-5.49)$ & $1.11(0.34-3.62)$ & $1.18(0.39-3.56)$ & $2.43(0.81-7.27)$ & $1.29(1.00-1.65)$ & 0.047 \\
\hline Adjusted odds ratio $(95 \% \mathrm{Cl})^{\mathrm{d}}$ & & Reference & $2.04(0.30-13.8)$ & $1.50(0.36-6.24)$ & $1.57(0.40-6.22)$ & $3.48(0.81-15.0)$ & $1.33(0.96-1.83)$ & 0.085 \\
\hline Patients without internal disease etiology & 233 & 34 & 23 & 53 & 86 & 37 & & \\
\hline In-hospital mortality (\%) & $32(13.7)$ & $6(17.6)$ & $1(4.3)$ & $3(5.7)$ & $13(15.1)$ & $9(24.3)$ & & \\
\hline Odds ratio $(95 \% \mathrm{Cl})$ & & Reference & $0.21(0.02-1.89)$ & $0.28(0.07-1.21)$ & $0.83(0.29-2.40)$ & $1.50(0.47-4.78)$ & $1.23(0.90-1.68)$ & 0.202 \\
\hline Adjusted odds ratio $(95 \% \text { Cl) })^{d}$ & & Reference & $0.59(0.04-8.37)$ & $1.17(0.14-9.54)$ & $3.96(0.56-28.2)$ & $10.0(1.13-88.8)$ & $2.07(1.23-3.48)$ & 0.006 \\
\hline \multicolumn{9}{|l|}{ Rewarming Procedure } \\
\hline Patients with active internal rewarming & 80 & 19 & 6 & 16 & 28 & 11 & & \\
\hline In-hospital mortality (\%) & $21(26.3)$ & $8(42.1)$ & $1(16.7)$ & $2(12.5)$ & $5(17.9)$ & $5(45.5)$ & & \\
\hline Odds ratio $(95 \% \mathrm{Cl})$ & & Reference & $0.28(0.03-2.83)$ & $0.20(0.03-1.12)$ & $0.30(0.08-1.13)$ & $1.15(0.26-5.11)$ & $0.89(0.62-1.27)$ & 0.513 \\
\hline Adjusted odds ratio $(95 \% \mathrm{Cl})^{\mathrm{e}}$ & & Reference & $0.26(0.01-5.37)$ & $0.23(0.01-3.74)$ & $0.33(0.03-4.44)$ & $3.42(0.26-45.3)$ & $1.29(0.71-2.36)$ & 0.408 \\
\hline Patients without active internal rewarming & 401 & 38 & 30 & 88 & 147 & 98 & & \\
\hline
\end{tabular}


Table 4 In-hospital mortality (subgroup analysis) (Continued)

\begin{tabular}{|c|c|c|c|c|c|c|c|c|}
\hline & \multirow{2}{*}{$\begin{array}{l}\text { All } \\
\text { patients }\end{array}$} & \multicolumn{5}{|c|}{ Rewarming rate $\left({ }^{\circ} \mathrm{C} / \mathrm{h}\right)$} & \multirow[t]{3}{*}{ Odds for trend } & \multirow{3}{*}{$\begin{array}{l}\mathrm{P} \text { for } \\
\text { trend }\end{array}$} \\
\hline & & $(\geq 2.0)$ & $(1.5-2.0)$ & $(1.0-1.5)$ & $(0.5-1.0)$ & $(<0.5)$ & & \\
\hline & $n=481$ & $n=57$ & $N=36$ & $n=104$ & $n=175$ & $n=109$ & & \\
\hline In-hospital mortality (\%) & $82(20.4)$ & $3(7.9)$ & $3(10.0)$ & $13(14.8)$ & $30(20.4)$ & $33(33.7)$ & & \\
\hline Odds ratio $(95 \% \mathrm{Cl})$ & & Reference & $1.30(0.24-6.94)$ & $2.02(0.54-7.55)$ & $2.99(0.86-10.4)$ & $5.92(1.69-20.7)$ & $1.63(1.27-2.08)$ & $<0.001$ \\
\hline Adjusted odds ratio $(95 \% \mathrm{Cl})^{\mathrm{e}}$ & & Reference & $1.52(0.24-9.49)$ & $1.86(0.43-8.08)$ & $2.91(0.70-12.1)$ & $6.14(1.38-27.4)$ & $1.63(1.19-2.25)$ & 0.002 \\
\hline
\end{tabular}

Values are expressed as numbers (percentages) unless indicated otherwise

adjusted for sex, body temperature at arrival to the hospital, the number of past medical history, activity of daily living, cold exposure, systolic blood pressure, internal disease etiology, active internal rewarming procedure

${ }^{b}$ Adjusted for sex, age category, body temperature at arrival to the hospital, the number of past medical history, activity of daily living, cold exposure, systolic blood pressure, internal disease etiology, active internal rewarming procedure

${ }^{c}$ Adjusted for sex, age category, the number of past medical history, activity of daily living, cold exposure, systolic blood pressure, internal disease etiology, active internal rewarming procedure

${ }^{\mathrm{d}}$ Adjusted for sex, age category, body temperature at arrival to the hospital, the number of past medical history, activity of daily living, cold exposure, systolic blood pressure, active internal rewarming procedure

${ }^{e}$ Adjusted for sex, age category, body temperature at arrival to the hospital, the number of past medical history, activity of daily living, cold exposure, systolic blood pressure, internal disease etiology

because of the haemodynamic instability due to severe hypothermia [5, 28-31]. However, considering the potential risk of complications with invasive rewarming methods [1], as well as the insufficient evidence that these methods improve the outcome in all patients with severe hypothermia, the best approach, not only for patient outcomes but also for healthcare cost, may be the stepwise approach that begins with active external and minimally invasive rewarming, and saving invasive method for patients who cannot be rewarmed adequately.

This study has several limitations. First, this was a retrospective chart review study; hence, missing data were unavoidable. A total of 54 patients were excluded because of missing data, but the number of patients included in this study is still the largest in this field. Second, we could not categorise patients whose RR was over $2.0^{\circ} \mathrm{C} / \mathrm{h}$ because of the small number of these patients. Thus, we plan to conduct a prospective study to obtain a larger number of patients. Third, although we have adjusted for the possible confounding factors, there may be residual confounding factors because of the retrospective design. Fourth, the proportion of 'cold exposure' was approximately $80 \%$ in this study. However, the possibility of underestimation of cold exposure could not be ruled out because we retrospectively obtained the data of this registry.

\section{Conclusion}

In this study, we found that overall, in-hospital mortality rates increase with each $0.5^{\circ} \mathrm{C} / \mathrm{h}$ decrease in RR. However, judging from the results of subgroup analyses, the safest RR might differ according to the patient status or rewarming methods.

\section{Acknowledgements}

The authors are deeply indebted to all members of the J-Point registry group for their contribution. The authors would also like to thank Ms. Marie Hara for study support.

\section{Authors' contributions}

TM and MW conceived the study, designed the trial, and obtained research funding. MW, TM, and $\mathrm{BO}$ supervised the conduct of the trial and data collection. SM, NE, NM, YO, TJ, YS, NO, MN, AT, YF, YO, and TK undertook recruitment of participating centres and patients and managed the data, including quality control. TM provided statistical advice on study design and analysed the data; TM chaired the data oversight committee. MW drafted the manuscript, and all authors contributed substantially to its revision. TM takes responsibility for the paper as a whole. All authors read and approved the final manuscript

\section{Funding}

none.

Availability of data and materials

The datasets used and/or analysed during the current study are available from the corresponding author on reasonable request.

Ethics approval and consent to participate

The ethics committee of each participating institution approved this study.

Consent for publication

Not applicable.

\section{Competing interests}

The authors declare that they have no competing interests.

\section{Author details}

${ }^{1}$ Department of Emergency Medicine, Kyoto Prefectural University of Medicine, Kamigyo-ku, Kyoto 602-8566, Japan. ${ }^{2}$ Senri Critical Care Medical Center, Saiseikai Senri Hospital, Suita, Japan. ${ }^{3}$ Department of Emergency, Japanese Red Cross Kyoto Daiichi Hospital, Kyoto, Japan. ${ }^{4}$ Department of Emergency Medicine, Rakuwa-kai Otowa Hospital, Kyoto, Japan. ${ }^{5}$ Department of Emergency and Critical Care Medicine, Japanese Red Cross Society Kyoto Daini Red Cross Hospital, Kyoto, Japan. 'Department of Emergency Medicine, Uji-Tokushukai Medical Center, Uji, Japan. ${ }^{7}$ Department of Emergency Medicine, North Medical Center, Kyoto Prefectural University of Medicine, Kyoto, Japan. ${ }^{8}$ Department of Emergency and Critical Care Medicine, National Hospital Organization, Kyoto Medical Centre, Kyoto, Japan. ${ }^{9}$ Department of Emergency and Critical Care Medicine, Saiseikai Shiga Hospital, Ritto, Japan. ${ }^{10}$ Department of Emergency and Critical Care Medicine, Kidney and Cardiovascular Center, Kyoto Min-iren Chuo Hospital, Kyoto, Japan. ${ }^{11 E m e r g e n c y ~ a n d ~ C r i t i c a l ~ C a r e ~ M e d i c a l ~ C e n t e r, ~ O s a k a ~ C i t y ~}$ General Hospital, Osaka, Japan. ${ }^{12}$ Department of Emergency Medicine, Fukuchiyama City Hospital, Fukuchiyama, Japan. ${ }^{13}$ Division of Environmental Medicine and Population Sciences, Department of Social and Environmental Medicine, Graduate School of Medicine, Osaka University, Osaka, Japan. 
Received: 29 July 2019 Accepted: 11 November 2019

Published online: 26 November 2019

\section{References}

1. Paal P, Gordon L, Strapazzon G, Brodmann MM, Putzer G, Walpoth B, et al. Accidental hypothermia-an update: the content of this review is endorsed by the International Commission for Mountain Emergency Medicine (ICAR MEDCOM). Scand J Trauma Resusc Emerg Med. 2016;24:111.

2. Japanese Association for Acute Medicine. The clinical characteristics of hypothermic patients in the winter of Japan - the final report of hypothermia STUDY 2011. J Jpn Assoc Acute Med. 2013;24:377-89.

3. Zafren K, Giesbrecht GG, Danzl DF, Brugger H, Sagalyn EB, Walpoth B, et al. Wilderness medical society practice guidelines for the out-of-hospital evaluation and treatment of accidental hypothermia: 2014 update. Wilderness Environ Med. 2014;25:S66-85.

4. Steele MT, Nelson MJ, Sessler DI, Fraker L, Bunney B, Watson WA, et al. Forced air speeds rewarming in accidental hypothermia. Ann Emerg Med. 1996:27:479-84

5. Morita S, Inokuchi S, Yamagiwa T, lizuka S, Yamamoto R, Aoki H, et al. Efficacy of portable and percutaneous cardiopulmonary bypass rewarming versus that of conventional internal rewarming for patients with accidental deep hypothermia. Crit Care Med. 2011:39:1064-8.

6. van der Ploeg GJ, Goslings JC, Walpoth BH, Bierens JJ. Accidental hypothermia: rewarming treatments, complications and outcomes from one university medical centre. Resuscitation. 2010;81:1550-5.

7. Headdon WG, Wilson PM, Dalton HR. The management of accidental hypothermia. BMJ. 2009;338:b2085.

8. Mallet ML. Pathophysiology of accidental hypothermia. QJM. 2002:95:775-85

9. Bernard SA, MacC Jones B, Buist M. Experience with prolonged induced hypothermia in severe head injury. Crit Care. 1999;3:167-72

10. Miller JW, Danzl DF, Thomas DM. Urban accidental hypothermia: 135 cases. Ann Emerg Med. 1980;9:456-61.

11. Cook DJ. CON: temperature regimens and neuroprotection during cardiopulmonary bypass: does rewarming rate matter? Anesth Analg. 2009; 109:1733-7.

12. Grigore AM, Grocott HP, Mathew JP, Phillips-Bute B, Stanley TO, Butler A, et al. The rewarming rate and increased peak temperature alter neurocognitive outcome after cardiac surgery. Anesth Analg. 2002;94:4-10.

13. Lu X, Ma L, Sun S, Xu J, Zhu C, Tang W. The effects of the rate of postresuscitation rewarming following hypothermia on outcomes of cardiopulmonary resuscitation in a rat model. Crit Care Med. 2014:42:e106-13.

14. Matsuyama T, Morita S, Ehara N, Miyamae N, Okada $Y$, Jo T, et al. Characteristics and outcomes of accidental hypothermia in Japan: the JPoint registry. Emerg Med J. 2018:35:659-66.

15. Brown DJ, Brugger H, Boyd J, Paal P. Accidental hypothermia. N Engl J Med. 2012:367:1930-8.

16. Kanda Y. Investigation of the freely available easy-to-use software 'EZR' for medical statistics. Bone Marrow Transplant. 2013;48:452-8.

17. Danzl DF, Pozos RS, Auerbach PS, Glazer S, Goetz W, Johnson E, et al. Multicenter hypothermia survey. Ann Emerg Med. 1987;16:1042-55.

18. Delaney KA, Vassallo SU, Larkin GL, Goldfrank LR. Rewarming rates in urban patients with hypothermia: prediction of underlying infection. Acad Emerg Med. 2006;13:913-21.

19. Biem J, Koehncke N, Classen D, Dosman J. Out of the cold: management of hypothermia and frostbite. CMAJ. 2003;168:305-11.

20. Broman M, Källskog O, Nygren K, Wolgast M. The role of antidiuretic hormone in cold-induced diuresis in the anaesthetized rat. Acta Physiol Scand. 1998;162:475-80.

21. Koht A, Cane R, Cerullo LJ. Serum potassium levels during prolonged hypothermia. Intensive Care Med. 1983;9:275-7.

22. Delaney KA, Howland MA, Vassallo S, Goldfrank LR. Assessment of acid-base disturbances in hypothermia and their physiologic consequences. Ann Emerg Med. 1989;18:72-82

23. Wolberg AS, Meng ZH, Monroe DM 3rd, Hoffman M. A systematic evaluation of the effect of temperature on coagulation enzyme activity and platelet function. J Trauma. 2004;56:1221-8.

24. Wang HE, Callaway CW, Peitzman AB, Tisherman SA. Admission hypothermia and outcome after major trauma. Crit Care Med. 2005:33: 1296-301.
25. Truhlář A, Deakin CD, Soar J, Khalifa GE, Alfonzo A, Bierens JJ, et al. European resuscitation council guidelines for resuscitation 2015: section 4. Cardiac arrest in special circumstances. Resuscitation. 2015;95:148-201.

26. Lloyd EL, Mitchell B. Factors affecting the onset of ventricular fibrillation in hypothermia. Lancet. 1974;2:1294-6.

27. Dietrichs ES, Tveita T, Smith G. Hypothermia and cardiac electrophysiology a systematic review of clinical and experimental data. Cardiovasc Res. 2018; https://doi.org/10.1093/cvr/cvy305.

28. Kjaergaard B, Bach P. Warming of patients with accidental hypothermia using warm water pleural lavage. Resuscitation. 2006;68:203-7.

29. Plaisier BR. Thoracic lavage in accidental hypothermia with cardiac arrestreport of a case and review of the literature. Resuscitation. 2005;66:99-104

30. Laniewicz M, Lyn-Kew K, Silbergleit R. Rapid endovascular warming for profound hypothermia. Ann Emerg Med. 2008;51:160-3.

31. Khorsandi M, Dougherty S, Young N, Kerslake D, Giordano V, Lendrum R, et al. Extracorporeal life support for refractory cardiac arrest from accidental hypothermia: a 10-year experience in Edinburgh. J Emerg Med. 2017;52: $160-8$.

\section{Publisher's Note}

Springer Nature remains neutral with regard to jurisdictional claims in published maps and institutional affiliations.
Ready to submit your research? Choose BMC and benefit from:

- fast, convenient online submission

- thorough peer review by experienced researchers in your field

- rapid publication on acceptance

- support for research data, including large and complex data types

- gold Open Access which fosters wider collaboration and increased citations

- maximum visibility for your research: over $100 \mathrm{M}$ website views per year

At BMC, research is always in progress.

Learn more biomedcentral.com/submissions 